\title{
REPRODUCTIVE RESPONSES OF NEWZEALAND WHITE RABBIT DOES FED ONCHEMICALLY AND BIOLOGICALLY TREATED CASTOR MEAL
}

\author{
Walaa, A. Salama; Marwa, A. Suliman; M. A. El-Shora and R.I.M. Matari \\ Animal Production Research Institute, Agricultural Research Center,. El-Dokki, Giza, Egyp. \\ Corresponding author: Walaa A. Salama, E-mail: Address: walaa.attia2@gmail.com
}

(Received 1/10/2015, Accepted 20/11/2015)

\section{SUMMARY}

\begin{abstract}
$\mathrm{R}$ eproductive trail was conducted to study the effects of two levels of chemically (CTCM) and biologically treated castor meal (BTCM) (replaced 20 or $40 \%$ from soybean meal in the diet) on reproductive performance, digestion coefficients, blood constituents and economic efficiency of New Zealand White (NZW) rabbit does. A total number of 40 New Zealand White (NZW) rabbit does age 5 months weighing $2.871 \pm 28.97 \mathrm{~kg}$ were used. Results indicate that the gestation length, total feed intake, daily feed intake, the change in body weight of the does during gestation and suckling period were not affected significantly $(\mathrm{P} \leq 0.05)$ by different treatments. Milk yield and milk composition were not significantly affected by feeding the experimental diets. Litter size at birth and litter size at weaning of kids, total litter gain, daily weight gain, total weight gain of kid and mortality\% of kids were not significantly $(\mathrm{P} \geq 0.05)$ affected by different treatments. However, litter weight at birth was significantly $(\mathrm{P} \leq 0.05)$ decreased in rabbits fed $40 \%$ BTCM and there were significant $(\mathrm{P} \leq 0.05)$ decrease in litter weight at weaning for rabbits fed 40\% CTCM and BTCM. The digestion coefficient of CP, CF, EE , NFE and (DCP\%), TDN\% and DE kcal $/ \mathrm{kg}$ were significantly lower with 40\% BTCM than those of the control, while the other tested diets mostly didn't significantly differ than those of the control group. Insignificant $(\mathrm{P} \geq 0.05)$ differences were observed in nitrogen balance among the different experimental groups. Plasma concentration values were insignificantly different for rabbits fed different tested diets (except serum urea which significantly decreased when rabbits fed on diets containing 40\% BTCM compared with the rabbits fed on control diet and there were significantly decreased in haemoglobin with rabbits fed on diet containing of $40 \%$ BTCM compared with those fed on control diet). it can be noticed that rabbist fed on the diets contained CTCM and BTCM at level 20\% had the best economic return between the experimental groups. It is concluded that chemically treated castor meal or biologically treated castor meal can be used up to $20 \%$ in rabbit does as a substitution from soybean meal without adverse effects in does performance, productive traits of kids and improve economic efficiency.
\end{abstract}

Keywords: chemically, biologically, castor meal, rabbits, reproductive and digestibility.

\section{INTRODUCTION}

Female reproduction is an interesting and attractive subject to study and preferred by many researchers as it is essential, important and beneficial for successful rabbits breeding. Litter size, birth weight and conception rate are so important economic traits in any productive animals. For great profit a special attention must be focused on these traits, so studying factors directly affecting them are so important and must be taken into consideration during breeding of any productive species (Mahmoud, 2013).

On the other hand, Castor oil bean (Ricinuscommunis) meal is a by-product of castor oil extraction industry. The castor oil plant (Ricinuscommunis L.) is a member of a spurge family of plants (Euphorbiaceae). It is grown commercially for the oil contained in the seed, which is used primarily for industrial purposes and in the manufacture of cosmetics. Most of the world's castor oils produced in India, China and Brazil, but commercial production also found on a small scale in many other tropical countries. World production of castor oil increased from 0.4 million tonnes in 1970 to 0.8 million tonnes in 2000 (Weiss, 2000). Castor oil bean meal contain from 35 to $40 \%$ crude protein and has potentials as an alternative source of vegetable protein in livestock feeds (Ani, 2012) and has been used in the feeding of poultry (Ani and Okorie, 2004; Oso et al., 2011). Ani and Okorie (2004), Ani and Okorie (2005) and Ani 


\section{Salama et al.}

(2012) showed that $10-15 \%$ useage of the meal could be satisfactorily used in poultry rations when properly detoxified. Detoxification becomes very necessary because of the presence of some toxic substances (ricinandricinine) and castor allergens in the raw bean (Olsnes, 2004; Audi et al., 2005; Ani and Okorie, 2005). The large-scale utilization of castor oil bean meal in livestock feeds has been limited due to these substances and its high level of abrasive fibre. A number of physical and chemical methods for detoxifying castor seed meal have been investigated. Physical treatments included Soaking (3, 6 and 12 hours), steaming (30 and $60 \mathrm{~min}$ ), boiling (30 and $60 \mathrm{~min}$.), autoclaving (15psi, $30 \mathrm{~min}$. or $60 \mathrm{~min}$.) and heating $\left(100^{\circ} \mathrm{C} 30 \mathrm{~min}\right.$; $\left.120^{\circ} \mathrm{C} 25 \mathrm{~min}\right)$, while the chemical methods consisted of treatment with ammonia ( Anandan et al., 2005; Martine z-Herrera et al., 2006; Nsa and Ukachukwu, 2007; Ani, 2012). However dry heat treatment could lead to the destruction of some amino acids, particularly lysine, threonine, tyrosine, cysteine and methionine, and the consequent reduction in the protein quality of the castor oil bean meal tends to limit the suitability of the method. Against this background and recognizing that castor oil bean meal can serve as an alternative source of vegetable protein in animal feed, the present study was undertaken to investigate the effects of dietary inclusion of castor meal on reproductive performance, digestion coefficients of nutrients, blood parameters and economical efficiency of New Zealand White (NZW) rabbits does.

\section{MATERIALS AND METHODS}

The experimental work of this study was carried out at Kafr EL-Sheikh Station belonging to Animal Production Research Institute, Agricultural Research Centre, Ministry of Agriculture, Egypt. The microbiological and chemical treatments were conducted at the Laboratories of By-Products Research Department, Animal Production Research Institute, Giza, Egypt. Castor meal was obtained from Elcaptain Company, Cairo, Egypt. It was ground by hammer mill and stored in an air-tight condition and kept for subsequent processing.

\section{Biological treatment:}

Fungal strain Penicillium funiculusms F-116 was obtained from Microbial Chemistry Department, National Research Centre, Dokki, Egypt. The microorganisms were preserved on Potato Dextrose Agar (PDA) medium at $25^{\circ} \mathrm{C}$ until used. About $50 \mathrm{~g}$ of castor meal was weighted and packed in heat resistant bags $(10 \times 20 \mathrm{~cm})$ and sterilized by autoclaving at $121^{\circ} \mathrm{C}$ for 30 minutes. Spore suspension of Penicillium funiculusms was prepared and used to inoculate $500 \mathrm{ml}$ capacity conical flasks containing $20 \mathrm{~g}$ of cooled sterilized residue, moistened by basal medium containing (g/L) 4\% molasses, $0.4 \%$ urea, $0.2 \% \mathrm{KH}_{2} \mathrm{PO}_{4}$ and $0.03 \% \mathrm{MgSO}_{4} .7 \mathrm{H}_{2} \mathrm{O}$ and incubated for 7 days (El-Ashry et al., 2002). The treated castor meal was moistened at $65-70 \%$ and put specific fungal spawn and left for three weeks.

\section{Chemical treatment:}

Castor meal was treated using calcium oxide solution, with each kg diluted in 10 litres of water and applied at $60 \mathrm{~g}$ of $\mathrm{CaO}$ per $\mathrm{kg}$ of castor meal as recommended by Oliveira et al., (2007). After mixing the meal with the $\mathrm{CaO}$ solution, the material rested for twelve hours (one night) and was then drained in a cemented area. The drying time, being varied according to the weather condition and was approximately $48 \mathrm{~h}$.

\section{Animal's management and feeding:}

Forty New Zealand White (NZW) does aged 5 months weighing $2.871 \pm 28.97 \mathrm{~kg}$ were housed separately in individual wired-cages. Mating was achieved by 5 adult New Zealand White bucks aged 6 months with good fertility records. Bucks were fed on control diet. All rabbits were kept under the same managerial and hygienic conditions and housed in metal battery cages supplied with separated feeders. Diets were offered adlibtium and fresh water was available all times from automatic nipple drinkers.

Five experimental diets were formulated, including the control diet without castor meal while, the other tested diets have chemically treated castor meal (CTCM) or biologically treated castor meal (BTCM) at 20 or $40 \%$ replacement of soybean meal ( 4.40 or $8.80 \%$ in basal diet). The ingredients of diets formulation and its chemical composition are presented in Table 1. All the experimental diets were formulated to be isonitrogenous and isocaloric, to meet all the essential nutrient requirements of growing rabbits (NRC, 1977).

\section{Reproductive performance:}

For does, the change in live body weight during gestation period was calculated as the difference between the live body weight at kindling and body weight post partum, while the change in live body 
weight during suckling was calculated as the difference between the live body weight at the end of suckling period (at weaning) (28 days post partum) and the body weight post partum.

The milk yield of each doe was recorded at the $7^{\text {th }}, 14^{\text {th }}, 21^{\text {st, }} 28^{\text {th }}$ days after kindling using the weightsuckle-weight technique described by McNitt and Lukefahr (1990). In this method the kits of each doe were separated from their dams by closing the gates between the nest box and the doe's cage, kits were allowed to suckle them by opening the gate. In the next morning the members of each litter were weighed (in grams) and returned again to the nest box. The litter after suckling was weighed again and milk yield was determined and recorded as the difference in the weight pre-and post suckling. Weekly milk yields (MY7, MY14, MY21 and MY28) were calculated as the mean of milk amount estimated in this week, and the multiplied by 7 to get the weekly milk yield. Total milk yield (TMY) of the first three weeks of suckling (TMY 21) was calculated as the mean of the milk amount of each week multiplied by 3 to get the total milk yield from birth up to 21 days. Milk samples were collected manually by gently massaging the mammary gland. Samples were taken per-doe per litter in the morning of the $21^{\text {st }}$ day of lactation. The samples were cooled and transferred to the laboratory for chemical analysis. Body weight and weight gain of kids were measured at birth and at weaning. Mortality rate (MR) during lactation for kids were calculated as:

Number of the kids born alive - Number of the kids at weaning

MR of kids $=\frac{\text { Number of the kids born alive }}{\text { Nung (During lactation) }}$

\section{Digestibility trials and nitrogen balance:}

Digestion trail was carried out to determine the digestion coefficients of nutrients and nutritive values of experimental diets used in the current experiment. Twenty NZW rabbit males, with same average live body weight were used in the digestion trail (4 rabbits/treatment). Rabbits were kept in individual metabolic cages which allowed a complete separation and collection of feces and urine. The males were fed the experimental diets from 10-14 days as a preliminary period followed by 6 days as a collection period during which the feces were collected daily sprayed with $2 \%$ boric acid solution for trapping any ammonia released from feces. At the end of this period, the feces were dried at $60^{\circ} \mathrm{C}$ for 48 hours (till constant weight), finely grounded and thoroughly mixed to ensure sample uniformity and then stored until being analysed. Urine was collected into buckets containing $0.1 \mathrm{ml}$ of HCL (10\%) to prevent $\mathrm{N}$ losses. The volume of urine at each sampling was recorded and sub-sample (10\%) was taken for each rabbit and stored at $-20^{\circ} \mathrm{C}$ for analysis of total $\mathrm{N}$ The chemical composition of feces, urine and feed was determined according to the methodologies described by Silva and Queiroz (2002).

\section{Chemical analyses:}

Analysis of castor meal, diets and feces and urine were carried out according to A.O.A.C. (2000). Data of quantities and chemical analysis of feed and feces were used to calculate the nutrient digestion coefficients and nutritive value for each dietary treatment, as described by Fekete (1985). The digestible energy of the experimental diets, castor meal, treated castor meal and soy bean meal were calculated according to Cheek (1987). The milk samples were collected and analyzed for fat, protein, lactose and ash according to methods of A.O.A.C. (2005).

\section{Blood parameters:}

Individual blood samples were taken at 9.00 am from the marginal ear vein and collected in $5 \mathrm{ml}$. heparinized test tubes and centrifuged at 3000 r.p.m for 20 minutes then plasma were transferred and stored in deep freezer at approximately $-20^{\circ} \mathrm{C}$ till the time of chemical analysis. Chemical analyses of the blood plasma were carried out for quantity determination of blood total lipids (Zollner and Kirsch, 1962), creatinine (Schirmeister, 1964), urea (Fawcett and Scott, 1960), total protein (Gornal et al., 1949), albumin (Doumas and Waston 1971), transaminase (AST, aspartate aminotransferase and ALT alanine aminotransferase, (Reitman and Frankle, 1957). HDL, LDL, Triglyceride, Haemoglobin, Red blood cell, Hematocrit (PCV), mean corpuscular volume (MCV), mean corpuscular haemoglobin (MCH), mean corpuscular haemoglobin concentration (MCHC), Platelet count, White cell count were determined by spectrophotometer. 


\section{Economical efficiency:}

The economical efficiency of experimental diets was calculated as the ratio between income (litter size $\mathrm{x}$ selling price of each rabbit at weaning) and cost of feed consumed according to Soliman et al., (2012).

\section{Statistical analysis:}

The experimental data were analyzed using general linear model using ANOVA procedures of SAS (2004) by the following model: $Y_{i j}=\mu+T_{i}+e_{i j}$.

Where: $\mu=$ overall mean of $Y_{i j}, T=$ effect of treatment, $i=(1,2 \ldots$, etc $)$ and $e_{i j}=$ experimental error.

The Significant differences among treatment means were separated at alpha level $(\mathrm{P} \leq 0.05)$ by Duncan's mu Di calcium phosphate ltiple range test (Duncan, 1955).

Table (1). Ingredients and chemical composition of experimental diets (on DM basis).

\begin{tabular}{|c|c|c|c|c|c|}
\hline \multirow[b]{2}{*}{ Ingredient } & \multirow{2}{*}{ Control diet } & \multicolumn{2}{|c|}{ CTCM } & \multicolumn{2}{|c|}{ BTCM } \\
\hline & & $20 \%$ & $40 \%$ & $20 \%$ & $40 \%$ \\
\hline Soybean meal (44\% CP) & 22.00 & 17.60 & 13.20 & 17.60 & 13.20 \\
\hline castor bean meal & ------- & 4.40 & 8.80 & 4.40 & 8.80 \\
\hline Barely grains & 26.00 & 26.00 & 26.00 & 26.00 & 26.00 \\
\hline Wheat bran & 20.90 & 20.90 & 20.90 & 20.90 & 20.90 \\
\hline Clover hay & 24.20 & 24.20 & 24.20 & 24.20 & 24.20 \\
\hline Lime stone & 0.70 & 0.70 & 0.70 & 0.70 & 0.70 \\
\hline Di calcium phosphate & 2.20 & 2.20 & 2.20 & 2.20 & 2.20 \\
\hline Sodium Chloride $(\mathrm{NaCl})$ & 0.30 & 0.30 & 0.30 & 0.30 & 0.30 \\
\hline Vit.\& min. Mix* & 0.30 & 0.30 & 0.30 & 0.30 & 0.30 \\
\hline DL-Methionine & 0.20 & 0.20 & 0.20 & 0.20 & 0.20 \\
\hline Anticoccidia (Diclazuril) & 0.20 & 0.20 & 0.20 & 0.20 & 0.20 \\
\hline Molasses & 3.00 & 3.00 & 3.00 & 3.00 & 3.00 \\
\hline Total & 100 & 100 & 100 & 100 & 100 \\
\hline \multicolumn{6}{|l|}{ Chemical analysis $(\%)$} \\
\hline DM\% & 89.40 & 90.06 & 89.76 & 90.17 & 90.26 \\
\hline \multicolumn{6}{|c|}{ Chemical analysis\% (on DM basis) } \\
\hline OM\% & 90.34 & 90.44 & 90.23 & 88.97 & 88.57 \\
\hline $\mathrm{CP} \%$ & 19.04 & 18.51 & 18.07 & 18.72 & 18.39 \\
\hline $\mathrm{CF} \%$ & 12.44 & 12.65 & 12.91 & 12.54 & 12.67 \\
\hline $\mathrm{EE} \%$ & 2.13 & 2.82 & 3.34 & 2.80 & 3.33 \\
\hline NFE\% & 56.73 & 56.46 & 55.91 & 54.91 & 54.18 \\
\hline Ash\% & 9.66 & 9.56 & 9.77 & 11.03 & 11.43 \\
\hline$* * \mathrm{DE}(\mathrm{kcal} / \mathrm{kg})$ & 2538.53 & 2531.75 & 2523.37 & 2535.30 & 2531.11 \\
\hline \multicolumn{6}{|l|}{ Calculated analysis $\%$} \\
\hline Total phosphorus & 0.896 & 0.891 & 0.886 & 0.891 & 0.886 \\
\hline Methonine & 0.478 & 0.515 & 0.576 & 0.515 & 0.552 \\
\hline Lysine & 1.018 & 1.005 & 0.993 & 1.005 & 0.993 \\
\hline \multicolumn{6}{|c|}{ 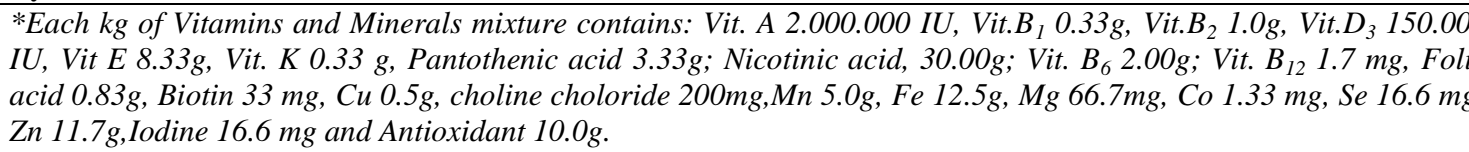 } \\
\hline
\end{tabular}

\section{RESULTS AND DISCUSSION}

\section{Chemical composition:}

Data presented in Table (2) showed the chemical analysis of castor meal (CM), chemically treated castor meal (CTCM) and biologically treated castor meal (BTCM) compared to soy bean meal. Where it contained comparable crude protein (33.56, 33.01 and 36.50 vs. 44.00\%), DE (2531.9, 2543.8 and 2620.6 
vs. 2814.2), CF (12.65, 12.28 and 9.90 vs. 3.90\%), EE (16.20, 16.32 and 16.50 vs. 1.90) and NFE (28.48, 24.98 and 25.09 vs. 43.80 , respectively). The obtained results showed that chemical treatment was markedly affected on the approximate analysis of castor meal. Nitrogen free extract has markedly decreased while, ash content was increased pronouncedly. The obtained results are in agreement with those reported by Diniz et al., (2010) who found that castor meal compared to castor meal treated with calcium oxide, had higher crude protein (35.78 vs. $34.44 \%$ ), ether extract (17.1 vs. $17.3 \%$ ). The efficiency of the alkaline treatment is attributed to ricin denaturation by lime. Denaturation represents extreme alterations in the threedimensional structure of a protein, which does not involve the breaking of peptide bonds and is almost always associated with loss of protein function (Lehninger et al., 1995). With alkaline treatment turning the protein net charge negative, provoking electrostatic repulsion and breaking the hydrogen bridges that support the three-dimensional structure (Oliveira, 2008). In addition to loss of function, hydrophobic groups are exposed during denaturation, resulting in decreased protein solubility in aqueous solutions. Therefore, the disappearance of ricin subunits indicates the loss of solubility in the extraction buffer at $\mathrm{pH}$ 3.8 , as shown by the changes for the denatured state of the toxin when submitted to alkaline treatment (60 $\mathrm{g}$ lime $/ \mathrm{kg}$ ) (Oliveira, 2008). Increasing ash content of CTCM may be due to increase minerals as calcium when treated with lime. Biological treatment had positive effects on improving the nutritive value of castor meal, since the protein contents was increased. This result is confirmed by Villas-Boas et al., (2002) who reported that biological treatment is used for increasing the nutritional value of many by-products because they have significant concentrations of simple carbohydrates such as mono and disaccharides. While, crude fibre content was reduced because microorganisms depend on this material as carbon source for growth and formation the microbial protein. Increasing ash content may be attributed to the growth or degradation of organic matter of castor bean meal by microorganism. Reduction in NFE could be related to the consumption of carbohydrates by the microorganism as energy sources for their growth and multiplication. These results are in good agreement with those reported by Abdel-Aziz et al., (2014) who found that biological treatments are paralleled with decreased crude fibre and fibre fractions content with increased crude protein content.

Table (2). Chemical analysis of soy bean meal, castor meal (CM), chemically (CTCM) and biologically treated castor meal (BTCM) on DM\% basis.

\begin{tabular}{|c|c|c|c|c|}
\hline Item & Soy bean meal & $\mathrm{CM}$ & CTCM & BTCM \\
\hline DM\% & 88.50 & 90.40 & 91.20 & 90.12 \\
\hline \multicolumn{5}{|c|}{ Chemical analysis\% (on DM basis) } \\
\hline OM\% & 93.60 & 90.89 & 86.59 & 87.99 \\
\hline $\mathrm{CP} \%$ & 44.00 & 33.56 & 33.01 & 36.50 \\
\hline $\mathrm{CF} \%$ & 3.90 & 12.65 & 12.28 & 9.90 \\
\hline $\mathrm{EE} \%$ & 1.90 & 16.20 & 16.32 & 16.50 \\
\hline NFE\% & 43.80 & 28.48 & 24.98 & 25.09 \\
\hline Ash\% & 6.40 & 9.11 & 13.41 & 12.01 \\
\hline $\mathrm{DE}(\mathrm{Kcal} / \mathrm{kg}) *$ & 2814.2 & 2531.9 & 2543.8 & 2620.6 \\
\hline
\end{tabular}

$* D E(\mathrm{kcal} / \mathrm{g})=4.36-0.0491 * \mathrm{NDF}$, Where $N D F \%=28.924+0.657 *$ CF\% according to Cheeke (1987).

\section{Performance of rabbit does during gestation period:}

Results of gestation length, total and daily feed intake, the change in body weight of the doe at mating and kindling and change in body weight of the doe between kindling and weaning of kids are illustrated in Table (3). The gestation length, total and daily feed intake and the change in body weight of the does at mating and kindling were not significantly affected $(\mathrm{P} \geq 0.05)$ by different treatments. Values of daily feed intake for does fed diets containing CTCM and BTCM were ranged between 150.66-155.29 g vs. 160.66 $\mathrm{g} /$ day for the control diet. Changes in body weight were between +100.04 and $+157.70 \mathrm{~g}$ vs. $+186.47 \mathrm{~g}$, respectively for the control diet. These results are in agreement with those of Silva et al., (2014) who found that supplementation with chemically treated castor meal in ewes does diets didn't affect pregnancy length, lambing rate. However, Salhab et al., (1999) showed that castor bean extract has negatively affected the processes of implantation and ovulation in rabbits and induced abortion in rats.

\section{Performance of rabbit does during suckling period:}

Table (4) indicates that feed intake and change in body weight of the does between kindling and weaning of kids, during suckling period, were not significantly affected by the different levels of CTCM and BTCM. Daily feed intake ranged between 228.57 and $233.92 \mathrm{~g}$ vs. $241.07 \mathrm{~g} / \mathrm{day}$, respectively for the control diet. Changes in body weight of the does due to treatments were between -57.00 and $-93.00 \mathrm{~g}$ vs. 
- $102.69 \mathrm{~g}$, respectively for the control diet. These results were similar those of Silva et al., (2014) who stated that live weight, body condition of ewes exhibited significant $(p<0.05)$ decrease in post-partum during suckling with supplementation of detoxified castor meal in ewe diets. The weight loss in suckling period due to the large supply of nutrients required for their maintance and milk production and they normally mobilize part of their body reserves to meet such demand (Silva et al., 2014). Feed intake decrease with increasing levels of castor meal during gestation and sucking period may be due to the negative palatability effect of castor meal.

Table (3). Means of performance traits of rabbit does as affected by different treatments during gestation periods.

\begin{tabular}{|c|c|c|c|c|c|c|}
\hline \multirow{2}{*}{ Item } & \multirow{2}{*}{ Control } & \multicolumn{2}{|c|}{ CTCM } & \multicolumn{2}{|c|}{ BTCM } & \multirow{2}{*}{ SEM } \\
\hline & & $20 \%$ & $40 \%$ & $20 \%$ & $40 \%$ & \\
\hline Gestation length (days) & 30.00 & 30.33 & 30.33 & 30.23 & 30.00 & 0.31 \\
\hline Total feed intake(kg/doe) & 4.82 & 4.71 & 4.65 & 4.60 & 4.52 & 0.049 \\
\hline Daily feed intake (g/doe) & 160.66 & 155.29 & 153.31 & 152.16 & 150.66 & 0.201 \\
\hline *Mating weight $(\mathrm{g})$ doe & 2917.21 & 2817.50 & 2914.33 & 2854.20 & 2850.30 & 28.97 \\
\hline$* *$ Gestation weight $(\mathrm{g})$ doe & 3103.68 & 2975.20 & 3038.21 & 2984.33 & 2954.30 & 26.23 \\
\hline$* * *$ Change in weight $(\mathrm{g})$ & +186.47 & +157.70 & +123.88 & +130.13 & +104.00 & 9.30 \\
\hline
\end{tabular}

Difference within the same row were not significantly different $(p \leq 0.05)$.

* Mating weight $(g)$ doe is live body weight at post partum.

**Gestation weight $(g)$ doe is live body weight at kindling.

$* * *$ Change in weight $(g)=$ Gestation weight $(g)$ - Mating weight $(g)$.

Table (4). Means of performance traits of rabbit does as affected by different treatments during suckling period.

\begin{tabular}{|c|c|c|c|c|c|c|}
\hline \multirow{2}{*}{ Item } & \multirow{2}{*}{ Control } & \multicolumn{2}{|c|}{ CTCM } & \multicolumn{2}{|c|}{ BTCM } & \multirow{2}{*}{ SEM } \\
\hline & & $20 \%$ & $40 \%$ & $20 \%$ & $40 \%$ & \\
\hline Total feed intake( $\mathrm{kg} /$ doe $)$ & 6.75 & 6.55 & 6.40 & 6.50 & 6.32 & 0.37 \\
\hline Daily feed intake (g/doe) & 241.07 & 233.92 & 228.57 & 232.14 & 225.71 & 4.30 \\
\hline *Mating weight $(\mathrm{g})$ doe & 2917.21 & 2817.50 & 2914.33 & 2854.20 & 2850.30 & 28.97 \\
\hline$* *$ Suckling weight $(\mathrm{g})$ doe & 2814.52 & 2724.00 & 2851.33 & 2770.39 & 2793.30 & 26.05 \\
\hline$* * *$ Change in weight $(\mathrm{g})$ & -102.69 & -93.50 & -63.00 & -83.81 & -57.00 & 7.47 \\
\hline
\end{tabular}

Difference with in the same row were not significantly different $(p \leq 0.05)$.

*Mating weight $(g)$ doe is live body weight at post partum.

**Suckling weight $)(g)$ doe is live body weight at the end of suckling period.

***Change in weight $(g)=$ Suckling weight $(g)$ - Mating weight $(g)$.

\section{Productive traits of kids:}

Productive traits of kids as affected by different treatments are presented in Table (5). Litter size at birth (total born), Litter size at birth (total alive), litter size at weaning of kids, total litter gain, daily weight gain, total weight gain of kid and mortality\% of kids were not significantly $(\mathrm{P} \geq 0.05)$ affected by different treatments. There were insignificant decrease of litter weight at birth and kid weight at birth for rabbits fed CTCM and BTCM at level $20 \%$ and 40\% CTCM and there were insignificant decrease of litter weight at weaning and kid weight at weaning for rabbits fed CTCM and BTCM at level 20\%. However, litter weight at birth and kid weight at birth were significantly $(\mathrm{P} \leq 0.05)$ decreased in rabbits fed $40 \%$ BTCM and there were significantly $(\mathrm{P} \leq 0.05)$ decrease in litter weight at weaning and kid weight at weaning for rabbits fed CTCM and BTCM at level 40\%. In this respect, Silva et al., (2014) found that supplementation of chemically treated castor meal in ewes does diets did not affect twinning rate, litter size and mortality post-partum. Moreover, Bhagwat et al. (2012) indicated that inclusion of 10\% chemically treated castor meal with calcium oxide did not have any adverse effect on feed conversion efficiency of lactating Mehsani buffaloes.

\section{Milk yield and composition:}

The milk yield and chemical composition of milk were insignificantly different between CTCM and BTCM diets (Table 6). Results here are supported by previous findings which with indicated that inclusion of $10 \%$ chemically treated castor meal with calcium oxide did not have any adverse effect on milk production and composition of lactating Mehsani buffaloes (Bhagwat et al., 2012). These results are 
in agreement with Silva et al., (2014) who found that supplementing chemically treated castor meal in ewes does diets did not affect milk production. And similar to those obtained by Cobianchi et al., (2012) who found that milk yield and composition were not affect up to $33 \%$ but decreased $(\mathrm{p}<0.05)$ with $67 \%$ soybean meal replacement by treated castor meal with calcium oxide in dairy cow rations. The reduction in milk yield occurred mostly due to the decrease in the production of lactose, which represents the main osmotic component of milk. The decrease in the production of lactose was a result of low intake of digestible carbohydrates (NFC and NDF), which reduced the flow of blood glucose in the mammary gland (Cobianchi et al. 2012).

Table (5). Means of productive traits of kids as affected by different treatments.

\begin{tabular}{|c|c|c|c|c|c|c|}
\hline \multirow{2}{*}{ Item } & \multirow{2}{*}{ Control } & \multicolumn{2}{|c|}{ CTCM } & \multicolumn{2}{|c|}{ BTCM } & \multirow{2}{*}{ SEM } \\
\hline & & $20 \%$ & $40 \%$ & $20 \%$ & $40 \%$ & \\
\hline Litter size at birth (total born) & 8.67 & 8.54 & 8.47 & 8.22 & 7.84 & 0.31 \\
\hline Litter size at birth (total alive) & 8.21 & 8.03 & 7.27 & 7.55 & 6.75 & 0.33 \\
\hline Litter size at weaning & 5.86 & 5.72 & 5.13 & 5.37 & 4.75 & 0.27 \\
\hline Litter weight at birth (g) & $455.00^{\mathrm{a}}$ & $430.00^{\mathrm{a}}$ & $344.00^{\mathrm{ab}}$ & $390.0^{\mathrm{ab}}$ & $290.00^{\mathrm{b}}$ & 22.18 \\
\hline Litter weight at weaning (g) & $2641.7^{\mathrm{a}}$ & $2535.30^{\mathrm{a}}$ & $2190.55^{b}$ & $2350.2^{\mathrm{ab}}$ & $2003.0^{\mathrm{b}}$ & 71.81 \\
\hline Total litter gain $(\mathrm{kg}) /$ doe & 1.722 & 1.6960 & 1.570 & 1.659 & 1.447 & 0.10 \\
\hline Kid weight at birth (g) & $55.42^{\mathrm{a}}$ & $53.54^{\mathrm{ab}}$ & $47.31^{\mathrm{ab}}$ & $51.65^{\mathrm{ab}}$ & $42.96^{\mathrm{b}}$ & 1.43 \\
\hline Kid weight at weaning (g) (28 day) & $450.80^{\mathrm{a}}$ & $443.23^{\mathrm{a}}$ & $427.00^{\mathrm{b}}$ & $437.65^{\mathrm{ab}}$ & $421.68^{b}$ & 3.33 \\
\hline Total weight gain of kid (g) & 395.38 & 389.69 & 379.69 & 386.00 & 378.72 & 5.75 \\
\hline Daily weight gain of kid (g) & 14.12 & 13.91 & 13.56 & 13.78 & 13.52 & 0.33 \\
\hline $\begin{array}{l}\text { Mortality } \% \text { of kids [from birth } \\
\text { (total alive) till weaning] }\end{array}$ & 28.62 & 28.67 & 29.43 & 28.87 & 29.62 & 0.42 \\
\hline
\end{tabular}

$a$ and $b$ means in the same row with different superscripts are significantly different $(P<0.05)$.

Table (6). Effect of treated castor meal on milk yield and composition.

\begin{tabular}{lcccccc}
\hline \multirow{2}{*}{ Item } & \multirow{2}{*}{ Control } & \multicolumn{2}{c}{ CTCM } & \multicolumn{2}{c}{ BTCM } & \multirow{2}{*}{ SEM } \\
\cline { 3 - 5 } & & $20 \%$ & $40 \%$ & $20 \%$ & $40 \%$ & \\
\hline Milk yield (kg/doe) & 2.53 & 2.45 & 2.00 & 2.37 & 1.98 & 0.090 \\
(4weeks) & 13.67 & 13.07 & 12.65 & 13.63 & 12.53 & 0.37 \\
Fat \% & 12.71 & 12.08 & 12.03 & 11.73 & 11.66 & 0.34 \\
Protein\% & 1.94 & 1.73 & 1.67 & 1.67 & 1.43 & 0.07 \\
Lactose\% & 2.91 & 2.69 & 2.86 & 2.61 & 3.02 & 0.14 \\
Ash\% & 31.23 & 29.57 & 29.21 & 29.64 & 28.64 & 0.45 \\
Total Solid & &
\end{tabular}

Difference within the same row was not significantly different $(p \leq 0.05)$.

\section{Nutrients digestibility:}

The digestion coefficients of the experimental diets of adult rabbits are shown in Table (7). These results indicate insignificant differences in DM and OM digestibility among different diets. There were insignificant decrease of digestion coefficients of crude protein $(\mathrm{CP})$, crude fibre $(\mathrm{CF})$, ether extract $(\mathrm{EE})$ and nitrogen free extract (NFE) when rabbits fed diets containing 20,40\% CTCM and 20\% BTCM (except digestion coefficient of NFE which significantly decreased with rabbits fed diets containing 40\% CTCM). However, digestion coefficients of $\mathrm{CP}, \mathrm{CF}, \mathrm{EE}$ and NFE were significantly $(\mathrm{P}<0.05)$ decreased with rabbits fed diets containing 40\% BTCM compared to those fed on control diet. In this respect, Suliman et al. (2015) found insignificant decrease digestion coefficients of $\mathrm{CP}, \mathrm{CF}$ and NFE when rabbits fed diets containing chemically and biologically treated castor meal at 20\% replacement of soybean meal. Moreover, Cobianchi et al., (2012) found the digestibility coefficients of DM, OM and CP were not affected when soybean meal was replaced castor meal treated with calcium oxide up to $67 \%$ in ration of dairy cows expect EE digestibility which was reduced $(\mathrm{P}<0.05)$. On the other hand, Oso et al. (2011) stated that utilization of fermented castor meal in starting cockerels chick diets at levels of 5, 10 and $15 \%$ did not affect on EE digestibility while increased CF digestibility. Also he stated that DM and CP digestibility were reduced with increasing fermented castor meal in the diet compared to control group. 
Table (7). Digestion coefficients of experimental diets.

\begin{tabular}{lllllll}
\hline \multirow{2}{*}{ Item } & \multirow{2}{*}{ Control } & \multicolumn{2}{c}{ CTCM } & \multicolumn{2}{c}{ BTCM } & SEM \\
\cline { 3 - 6 } & & $20 \%$ & $40 \%$ & $20 \%$ & $40 \%$ & \\
\hline DM \% & 71.80 & 68.64 & 66.02 & 67.64 & 62.00 & 1.31 \\
OM \% & 70.47 & 65.14 & 65.32 & 62.03 & 60.01 & 1.21 \\
CP \% & $74.61^{\mathrm{a}}$ & $74.43^{\mathrm{a}}$ & $70.60^{\mathrm{ab}}$ & $71.83^{\mathrm{ab}}$ & $65.61^{\mathrm{b}}$ & 1.30 \\
$\mathrm{CF} \%$ & $42.71^{\mathrm{a}}$ & $40.04^{\mathrm{ab}}$ & $29.56^{\mathrm{ab}}$ & $28.34^{\mathrm{ab}}$ & $26 . .30^{\mathrm{b}}$ & 2.36 \\
EE \% & $78.39^{\mathrm{a}}$ & $76.95^{\mathrm{a}}$ & $72.93^{\mathrm{ab}}$ & $72.34^{\mathrm{ab}}$ & $67.06^{\mathrm{b}}$ & 1.32 \\
NFE \% & $77.06^{\mathrm{a}}$ & $76.12^{\mathrm{ab}}$ & $71.68^{\mathrm{bc}}$ & $74.15^{\mathrm{abc}}$ & $69.54^{\mathrm{c}}$ & 0.93 \\
\hline
\end{tabular}

$a, b, c$, means in the same row with different superscripts are significantly different $(P \leq 0.05)$.

\section{Nutritive value and nitrogen balance:}

The nutritive value and nitrogen balance (NB) of the experimental diets of the doe rabbits are listed in Table (8). These results show that digestible crude protein (DCP \%) total digestible nutrients (TDN\%) and digestible energy (DE kcal/kg) were significantly lower with 40\% BTCM than control one, while the other tested diets mostly didn't significantly differ compared to control group in these parameters. These results are in good agreement with those reported by Suliman et al., (2015) who observed that DCP, TDN and DE were significantly lower with $40 \%$ BTCM diet than control one, while the other tested rabbits diets mostly didn't significantly differ in these parameters than the control group. Oliveira et al., (2010) concluded that the decrease in $\mathrm{CP}$ digestibility was probably due to the decrease in CP intake, which increase the participation of the fecal metabolic fraction which applies to the recent results as total feed consumption was reduced with the $40 \%$ BTCM (table 3 and 4). In this respect, Bhagwat et al., (2012) indicated that inclusion of $10 \%$ chemically treated castor meal with calcium oxide did not have any adverse effect on DCP and TDN of lactating Mehsani buffaloes .

As shown in Table (8), results indicate insignificant decrease in nitrogen balance (NB) when rabbits were fed on diets containing CTCM and BTCM at levels $20 \%$ while, $40 \%$ CTCM and BTCM recorded significant $(\mathrm{P}<$ 0.05) decrease when compared to the rabbits fed on control diet. These results were similar to those reported by Cobianchi et al. (2012) who found that the nitrogen balance was not affected by chemically castor $(\mathrm{P}<0.05)$ up to $67 \%$ replacement of soybean meal in dairy cow diets, indicating that nitrogen intake meet the nitrogen requirement of cows.

In general, the improvement of digestibility of all nutrients, nutritive value, in adult rabbits fed diets containing CTCM compared to rabbits fed diets containing BTCM may be due to the better efficiency of chemical treatment than biological treatment respecting to reduced toxicity level of the castor meal. (Oliveira $e t$ al. 2007) stated that treatment with calcium oxide or calcium hydroxide $(60 \mathrm{~g} / \mathrm{kg}$ castor meal) completely removed ricin from castor meal. Moreover, Diniz et al. (2010) found that using lime treatment (calcium oxide) $(60 \mathrm{~g} / \mathrm{kg}$ castor meal) reduced ricin by $96.6 \%$. While, Godoy et al. (2009) found that using certain fungi such as penicillium simplicissimum reduced ricin by only $16 \%$. The reduction of all nutrients digestibility, nutritive value, in rabbits doe fed $40 \%$ BTCM may be due to the increased residual effects of castor allergen in castor meal which increased with increasing the level of BTCM in the diet.

Table (8). Nutritive value and nitrogen balance of experimental diets.

\begin{tabular}{lllllll}
\hline \multirow{2}{*}{ Item } & \multirow{2}{*}{ Control } & \multicolumn{3}{c}{ CTCM } & \multicolumn{3}{c}{ BTCM } & \multirow{2}{*}{ SEM } \\
\cline { 3 - 6 } & & $20 \%$ & $40 \%$ & $20 \%$ & $40 \%$ & \\
\hline DCP \% & $13.80^{\mathrm{a}}$ & $13.55^{\mathrm{a}}$ & $12.70^{\mathrm{ab}}$ & $13.09^{\mathrm{ab}}$ & $11.88^{\mathrm{b}}$ & 0.192 \\
TDN\% & $68.09^{\mathrm{a}}$ & $67.92^{\mathrm{a}}$ & $63.72^{\mathrm{ab}}$ & $64.89^{\mathrm{ab}}$ & $60.39^{\mathrm{b}}$ & 1.04 \\
DE kcal/kg* & $3016.38^{\mathrm{a}}$ & $3008.85^{\mathrm{a}}$ & $2822.79^{\mathrm{ab}}$ & $2874.62^{\mathrm{ab}}$ & $2675.27^{\mathrm{b}}$ & 46.47 \\
NB \% & 69.75 & 67.86 & 62.77 & 61.52 & 60.58 & 2.49 \\
\hline
\end{tabular}

*DE $=T D N X 44.3$ according to (Schneider and flat, 1975).

$a$ and $b$ means in the same row with different superscripts are significantly different $(P<0.05)$. 


\section{Blood constituents:}

Plasma concentration values of total protein, albumin, HDL, LDL, total lipid, triglyceride, urea, creatinine, aspartate aminotransferase (AST) and alanine aminotransferase (ALT) are shown in Table (9). The obtained values of blood parameters were within the normal range. It could be noticed insignificantly differences in concentration of those values for rabbits fed different tested diets. However, urea was significantly decreased with rabbits fed on diet containing BTCM at level $40 \%$ compared to those fed on control diet. Oso et al., (2011) stated that utilization of fermented castor meal in starting cockerels chicks diet were did not affect on total protein, albumin, globulin and uric acid. and creatinine was significantly increased when dietary level of fermented castor meal increased in the diet. Suliman et al., (2015) observed that plasma concentration values of total protein, albumin, globulin, cholesterol, total lipid, creatinine, ALT and AST were did not differ in rabbits fed chemically and biologically treated castor meal up to $40 \%$ replacement of soybean. These results somewhat agree with those obtained by Cobianchi et al., (2012) who found that AST, ALT and urea concentration were insignificantly different among dairy cows fed on castor meal treated by calcium oxide up to $33 \%$ replacement of soybean meal. Also, Silva et al., (2014) found that supplementation of chemically treated castor meal in ewes diets led to insignificantly decrease in albumin and triglyceride level while, significantly $(\mathrm{P}<0.05)$ decreased glucose, urea, protein and cholesterol level.

Table (9). Some blood constituents of rabbit does fed on experimental diets.

\begin{tabular}{lcccccc}
\hline \multirow{2}{*}{ Item } & \multirow{2}{*}{ Control } & \multicolumn{2}{c}{ CTCM } & \multicolumn{2}{c}{ BTCM } & \multirow{2}{*}{ SEM } \\
\cline { 3 - 6 } & & $20 \%$ & $40 \%$ & $20 \%$ & $40 \%$ & \\
\hline Total protein, g/dl & 5.24 & 5.61 & 6.02 & 5.82 & 6.19 & 0.168 \\
Albumin, g/dl & 4.39 & 4.26 & 3.57 & 3.94 & 3.95 & 0.146 \\
HDL mg/dl & 64.16 & 62.18 & 59.62 & 53.46 & 50.89 & 2.87 \\
LDL mg/dl & 134.91 & 138.95 & 165.54 & 145.80 & 178.77 & 7.02 \\
Total lipid mg/dl & 347.75 & 357.66 & 360.36 & 339.64 & 363.96 & 7.91 \\
Triglyceride mg/dl & 82.00 & 80.36 & 73.58 & 80.96 & 79.39 & 1.22 \\
Urea-N, mg/dl & $48.40^{\mathrm{a}}$ & $46.35^{\mathrm{ab}}$ & $43.04^{\mathrm{b}}$ & $44.46^{\mathrm{ab}}$ & $43.69^{\mathrm{b}}$ & 0.72 \\
Creatinine mg/dl & 0.656 & 0.696 & 0.773 & 0.723 & 0.786 & 0.020 \\
AST(U/L) & 46.66 & 48.66 & 54.00 & 44.66 & 55.00 & 0.78 \\
ALT(U/L) & 57.66 & 59.33 & 62.66 & 60.66 & 64.33 & 0.99 \\
\hline
\end{tabular}

$a$, and $b$ means in the same row with different superscripts are significantly different $(\mathrm{P} \leq 0.05)$.

\section{Haematological parameters:}

Statistical analysis of haematological values of haemoglobin, red blood cell, hematocrit (PCV), MCV, $\mathrm{MCH}, \mathrm{MCHC}$, platelet count and white cell count are listed in Table (10).

Table (10). Haematological parameters of rabbit does fed on experimental diets.

\begin{tabular}{|c|c|c|c|c|c|c|}
\hline \multirow{2}{*}{ Item } & \multirow{2}{*}{ Control } & \multicolumn{2}{|c|}{ СТCM } & \multicolumn{2}{|c|}{ BTCM } & \multirow{2}{*}{ SEM } \\
\hline & & $20 \%$ & $40 \%$ & $20 \%$ & $40 \%$ & \\
\hline Haemoglobin g/dl & $13.20^{\mathrm{a}}$ & $12.10^{\mathrm{ab}}$ & $10.82^{\mathrm{ab}}$ & $11.16^{\mathrm{ab}}$ & $10.60^{\mathrm{b}}$ & 0.36 \\
\hline Red blood cell $10^{6} / \mathrm{mm}^{3}$ & 5.72 & 5.51 & 4.66 & 5.28 & 4.60 & 0.26 \\
\hline Hematocrit\% (PCV) & 42.10 & 41.05 & 38.18 & 39.20 & 36.70 & 1.03 \\
\hline $\mathrm{MCV} \mathrm{mm}^{3}$ & 64.00 & 61.43 & 54.46 & 59.54 & 52.53 & 2.87 \\
\hline $\mathrm{MCH}, \mathrm{pg} / \mathrm{cell}$ & 23.06 & 20.36 & 19.62 & 18.66 & 18.66 & 0.70 \\
\hline $\mathrm{MCHC} \%$ & 29.30 & 30.32 & 28.30 & 30.02 & 27.33 & 0.70 \\
\hline Platelet count $10^{3} \mathrm{~mm}^{3} / 1$ & 255.32 & 269.20 & 297.3 & 268.21 & 306.2 & 28.94 \\
\hline White cell count $10^{9} / 1$ & 7.30 & 6.70 & 5.80 & 6.30 & 5.60 & 0.37 \\
\hline
\end{tabular}

$a$, and $b$ means in the same row with different superscripts are significantly different $(P \leq 0.05)$.

All values were insignificantly different for rabbits fed experimental diets except haemoglobin recorded significant $(\mathrm{p}<0.05)$ decrease with rabbits fed 40\% BTCM compared to those fed on control diet. In these respect, Akande et al., (2013) indicated that $\mathrm{RBC}, \mathrm{Hb}, \mathrm{MCV}, \mathrm{MCH}$ and $\mathrm{MCHC}$ decreased 


\section{Salama et al.}

$(\mathrm{P}<0.05)$ but hematocrit, white cell count, neutrophils were not significantly affected when layer fed treated castor meal and untreated castor meal compared to control group.

\section{Economical efficiency:}

The economical efficiency of the present study was calculated based upon input-output analysis of the total feeding cost / doe and the prevailing selling price of the litter/doe at weaning (Table 11). Results indicated that the lowest total feed cost /doe (LE.) (30.02 LE.) was observed with rabbits fed the diets containing 40\% BTCM followed by those fed 40\% CTCM (31.27 LE.). Results indicated that groups fed the diets contained 20\% CTCM and 20\% BTCM were achieved the highest economical efficiency (1.394 and 1.304) and relative economical efficiency (108.90 and 101.87) followed by a decreasing order by groups fed $40 \%$ CTCM and the least was the group fed 40\% BTCM. These results are in agreement with Bhagwat et al., (2012) who found that buffaloes fed $10 \%$ chemical treated castor cake based concentrate mixture recorded $24.25 \%$ higher return over feed cost than the control group and thus has economic advantage in the lactating buffaloes.

Table (11). Effect of treated castor meal on economical efficiency of rabbit does.

\begin{tabular}{|c|c|c|c|c|c|}
\hline \multirow{2}{*}{ Item } & \multirow{2}{*}{ Control } & \multicolumn{2}{|c|}{ CTCM } & \multicolumn{2}{|c|}{ BTCM } \\
\hline & & $20 \%$ & $40 \%$ & $20 \%$ & $40 \%$ \\
\hline Price $/ \mathrm{kg}$ diet & 3.11 & 2.97 & 2.83 & 2.94 & 2.77 \\
\hline Total feed consumed doe/gestation period $/ \mathrm{kg}$ & 4.82 & 4.71 & 4.65 & 4.60 & 4.52 \\
\hline Total feed consumed doe/suckling period $/ \mathrm{kg}$ & 6.75 & 6.55 & 6.40 & 6.50 & 6.32 \\
\hline Total feed cost /doe (LE) & 35.98 & 33.44 & 31.27 & 32.63 & 30.02 \\
\hline Litter size at weaning & 5.86 & 5.72 & 5.13 & 5.37 & 4.75 \\
\hline Total revenue/ Litter at weaning (LE) ${ }^{1}$ & 82.04 & 80.08 & 71.82 & 75.18 & 66.50 \\
\hline Net revenue/doe $(\mathrm{LE})^{2}$ & 46.06 & 46.64 & 40.55 & 42.55 & 36.48 \\
\hline Economic efficiency $(\mathrm{LE})^{3}$ & 1.280 & 1.394 & 1.296 & 1.304 & 1.215 \\
\hline Relative economic efficiency & 100 & 108.90 & 101.25 & 101.87 & 94.92 \\
\hline
\end{tabular}

${ }^{1}$ Total revenue $=$ Litter size $x 14$, assuming that the selling price of each rabbit at weaning was LE (14).

${ }^{2}$ Net revenue/ rabbit doe $(L E)=$ Total revenue/ rabbit doe $(L E)-$ Total feed cost / rabbit doe $(L E)$.

${ }^{3}$ Economic efficiency $=$ Net revenue/ rabbit doe/ Total feed cost $/$ rabbit doe (LE).

Generally, it can be noticed that rabbit fed on the diets containing CTCM and BTCM at level 20\% had the best economic return over other treatments.

\section{CONCLUSION}

It is concluded that chemically treated castor meal or biologically treated castor meal can be used up to $20 \%$ in rabbit does diets as a substitution from soybean meal without adverse effects in does performance and productive traits of kids and improve economic efficiency. Also, improvement of reproductive performance of rabbits fed CTCM compared to those fed BTCM.

\section{REFERENCES}

Abdel-Aziz Nahla, A.; Z.M.S. Abdel fattah; M.M. El-Adawy; L.M. Camacho; A.E. Kholif, M.Y. Elghandour Mona and B.E. Borhami. (2014). Biological treatments and feeding sugarcane bagasse in agriculture animals - an overview. J. Integ. Agric. Adva., 8: 1-25

Akande, T.O.; A.A. Odunsi; T.A. Rafiu; C.O. Olaniyi and R.T. Binuomote (2013). Growth and serological assessment of broiler chickens fed differently processed castor (Ricinuscommunis Linn.) kernel cake based diets. African Journal of Agricultural Research, 8(41): 5161-5165.

Anandan, S.; G. Kumar; J. Ghosh and K. Ramachandra (2005).Effect of different physical and chemical treatments on detoxification of ricin in castor cake. Anim. Feed Sci. and Techn., 120: 159-168. 
Ani, A.O. and A.U. Okorie (2004). The effect of dietary castor oil bean (Ricinuscommunis L.) meal and supplementary L-Lysine on the performance of broiler starter chicks. Discov \& Innov., 16(1/2): 4652.

Ani, A.O. and A.U. Okorie (2005). The effects of graded levels of de hulled and cooked castor oil bean (Ricinuscommunis L.) meal on performance of broiler starters. Nig. J. Anim. Prod., 32(1): 54-60.

Ani, A.O. (2012). Nutritional Evaluation of Castor oil bean (Ricinuscommunis L.) Meal Lambert Academic Publishers, Saarbrucken eutsch land (Germany), 172pp.

A.O.A.C. (2000).Official methods of analysis. $17^{\text {th }}$ ed., published by the A.O.A.C., Washington, D.C., USA.

A.O.A.C. (2005).Official methods of analysis. $17^{\text {th }}$ ed., published by the A.O.A.C., Washington, D.C., USA.

Audi, J.M.; M. Belson; J. Patel, Schier and J. Osterloh (2005). Ricin poisoning-acomprehensive review. JAMA, 294: 2342-2351.

Bhagwat, S.R.; S. Parnerkar and Sanjay B. Patil. (2012). Effect of feeding detoxified castor seed cake in lactating buffaloes. Journal of Animal and Plant Sciences, 22(3 Suppl.): 205-206.

Cheeke, P.R. (1987). Rabbitfeeding and nutrition.Academic Press Orlando, Florida, USA, 376 p.

Cobianchi, J.V.; A.S. de Oliveira; J.M.S. Campos, A.V.S. Campos; S.C. Valadares Filho; F.C. Pereira and T.E.S. de Oliveir (2012). Productive performance and efficiency of utilization of the diet components in dairy cows fed castor meal treated with calcium oxide. Revista Brasileira de Zootecnia, 41: 2238-2248.

Diniz, L.L.; S.C. Valadares Filho; J.M.S. Campos; R.F.D. Valadares; L.D. da Silva; J.P.I.S. Monnerat ; P.B. Benedeti; A.S. de Oliveira and D.S. Pina (2010). Effect of castor meal on the growth performance and carcass characteristics of beef cattle. Asian Aust. J. Anim. Sci., 23: 1308-1318.

Doumas, B.T. and W. Waston (1971). Albumin standards and measurement of plasma albumin with bromocresol green. Clin. Chem. Acta., 31: 87.

Duncan, D.B. (1955). Multiple Range and Multiple F-Test. Biometrics, 11: 1-42.

El-Ashry, M.A; H.M. El-Sayed, M. Fadel. H.M. Metwally and M.M Khorshed (2002). Effect of chemical and biological treatments of some crop residues on their nutritive value. Egyptian J. Nutrition and Feeds, 5(1): 43-54.

Fawcett, J.K. and J. E. Scott (1960). Determination of urea. J. Clic. Path., 13: 156-159.

Fekete, S. (1985). Rabbit feeds and feeding with special regard to tropical condition. J. Applied Rabbit Research, 8: 167-173.

Godoy, M.G.; M.L.E. Gutarra; F.M. Maciel; S.P. Felix; J.V. Bevilaqua; O.L.T. Machado and D.M.G. Freire(2009). Use of a low-cost methodology for bio detoxification of castor bean waste and lipase Production enzyme and microbial technology, 44: 317-322.

Gornal, A.G.; C.J. Bardawill and M.M. Divid (1949). Determination of plasma protein by means of the biurent reaction. J. Biol. Chem., 177: 751.

Lehninger, A.L.; D.L. Nelson and M.M. Cox (1995). Princípios de Bioquímica. Tradução: Simões, A.A.; Lodi, W.R.N. 2.ed. São Paulo: Sarvier.

Mahmoud, E.A.A. (2013). Studies on some factors affecting doe, buck and litter performance in white New Zealand rabbit under Egyptian condition. Benha Veterinary Medical Journal, 25(2): 1-12.

Martinez-Herera, J.,P; G. Siddhuraju; G. Francis; Davila-Ortiz and K. Becker (2006). Chemical composition, toxic/anti-metabolic constituents, and effects of different treatments on their levels, in four provenances of Jatrophacurcas L. from Mexico. Food Chem., 96: 80-89.

McNitt, J.I. and D. Lukefahr (1990). Effect of breed, parity and days of lactation of rabbits. J. Anim. Sci., 68: $1505-1512$

Nsa, E.E. and S.N. Ukachukwu (2007). Determination of the true metabolizable energy of raw and thermal treated castor bean (Ricinuscommunis) using adult broiler birds Proc. Ann. Conf. of Nig. Soci. for Anim. Prod., 32: 287-289. 


\section{Salama et al.}

NRC (1977). National Research Council. Nutrient requirements of rabbits. Nat. Acad. Sci., Washington, DC., USA.

Olsnes, S. (2004). The history of ricin, a brin and related toxins. Toxic, 44: 361-370.

Oliveira, A.S. (2008). Co-produtos da extração de óleos de sementes de mamona e de girassolnaalimentação de ruminantes. Viçosa, MG, 2008. p. 165.Tese (DoutoradoemZootecnia), Universidade Federal de Viçosa (cited after Diniz et al., 2010).

Oliveira, A.S.; M.R.C. Oliveira and J.M.S. Campos (2007). Eficaciade di ferentesmetodos de destoxificaçao da ricina do farelo de mamona. In: II Congresso da Rede Brasileira de Tecnologia de

Oliveira, A.S.; J.M.S. Campos and M.R.C. Oliveira (2010). Nutrient digestibility, nitrogen metabolism and hepatic function of sheep fed diets containing solvent or expeller castor seed meal treated with calcium hydroxide. Anim. Feed Sci. and Techn., 158:15-28.

Oso, A.O.; W.A. Olayemi; A.M. Bamgbose and O.F. Fowoyo (2011). Utilization of fermented castor oil seed (Ricinuscommunis, L.) meal in diets for cockerel chicks. Arch. Zootec., 60: 75-82.

Reitman, S. and S. Frankel (1957). Determination of GOT and GPT Amr. J. Clin. Path., 28:56-63.

Salhab, A.S.; M.S. Shomaf; M.N. Gharaibeh and N.A. Amer (1999). Effects of castor bean extract and ricin A- chain on ovulation and implantation in rabbits. Contraception, 59: 395-399.

SAS (2004). User's guide. Statistic.SAS Inst. Cary, N.C. Releigh.

Schirmeister, J. (1964). Determination of creatinine. Dtsch. Med Wschr., 89: 1940.

Silva, D.J. and A.A.C. Queiroz (2002). Analysis foods: chemical and biologicalmethods.3. ed.Viçosa, MG: UFV, 235p.

Silva, L.M.; A. M Silva; C. H. A Oliveira; H. A.V. Carneiro; P.T. Souza; F.J. Beserra; C.M.J. Silva; D. Rondina (2014). Reproductive responses and productive characteristics in ewes supplemented with detoxified castor meal for a long period. R. Bras. Zootec.. 43(8): Viçosa.

Soliman, A.Z.M.; M.A.F. El-Manylawi; Fatma G. Ahmed; Fatma T.F. Abd- El Ghany (2012). Reproductive performance of New Zealand white rabbit does fed on diets containing corn distiller's dried grains with soluble. $3^{\text {rd }}$ Mediterranean Poultry Summit and $6^{\text {th }}$ International Poultry Conference, 26 -29 March, Alexandria, Egypt.

Suliman, M.A.; W.A. Salama,; R.I.M. Matari and M.A. El-Shora (2015). Productive performance of new Zealand white growing rabbits fed on diets containing different levels of treated castor meal. Egyptian J. Nutrition and Feeds, 18 (2) Special Issue: 361-370.

Villas-Boas, S.G.; E. Esposito and D.A. Mitchell (2002).Microbial conversion of lingo cellulosic residues for production of animal feeds. Anim. Feed Sci. and Techn., 98: 1-2.

Weiss, E.A. (2000). Castor. In “Oilseed Crops, $2^{\text {nd }}$ Edition”, Blackwell Scientific Ltd., Oxford. pp13-52.

Zollner, N. and K. Kirsch (1962). Determination of total lipids in blood by Colorimetric Method. Z. Ges. Exp. Med., 135: 454- 454. 


\title{
الإستجابه التناسليه لأمهات الأرانب النيوزيلندي الأبيض المغذاه على كسب الخروع المعامل كيميائيا وبيولوجيا
}

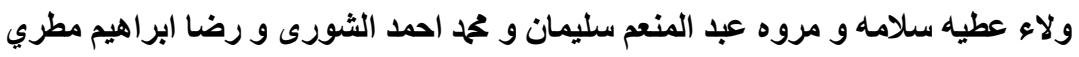

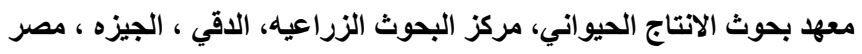

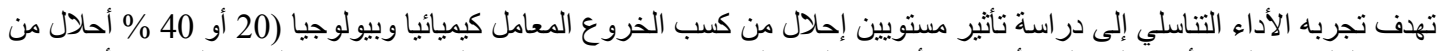

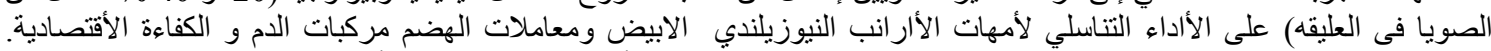

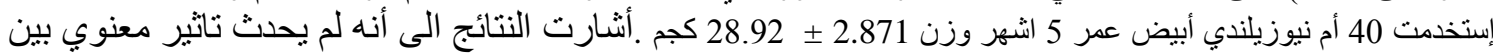

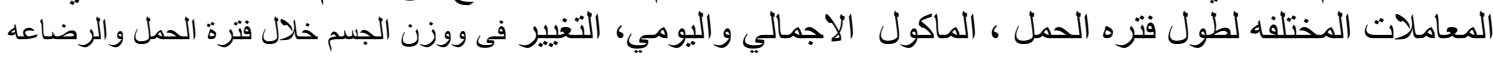

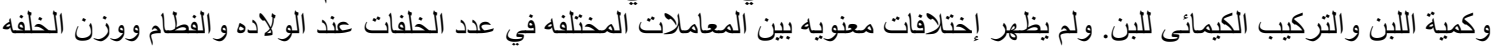

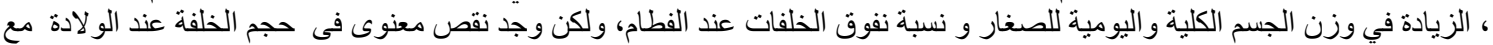

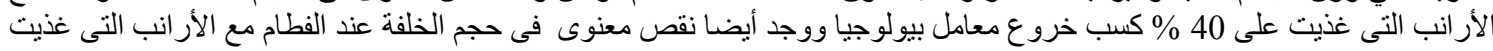

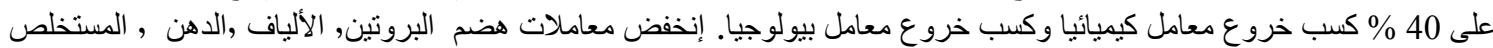

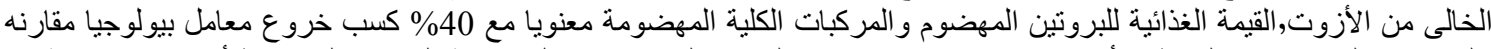

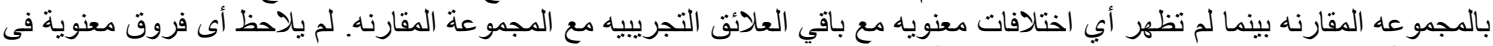

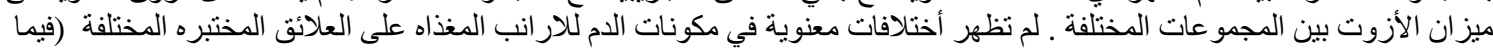

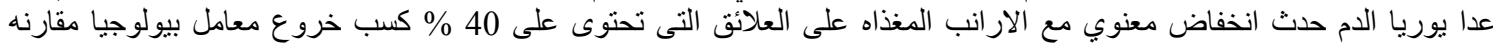

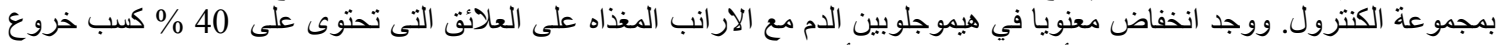

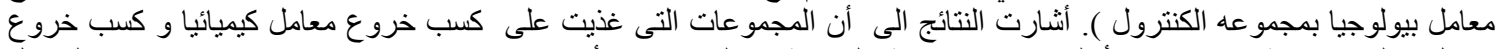

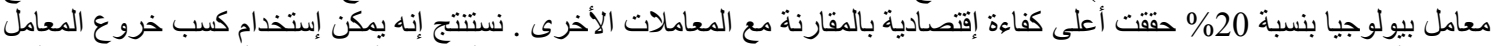

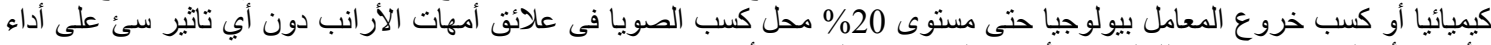
الأمهات أو الصفات الانتاجيه للخلفات بالأضافة الى تحسين الكفاءة الأقتصادية.

الكلمات الداله: كبيائيا، بيولوجيا، كسب الذروع، ارانب، تناسلي، هضم 